2015-12

The acute toxicity of thallium to freshwater organisms: Implications for risk assessment

\title{
Tatsi, K
}

http://hdl.handle.net/10026.1/4939

10.1016/j.scitotenv.2015.06.069

Science of The Total Environment

Elsevier BV

All content in PEARL is protected by copyright law. Author manuscripts are made available in accordance with publisher policies. Please cite only the published version using the details provided on the item record or document. In the absence of an open licence (e.g. Creative Commons), permissions for further reuse of content should be sought from the publisher or author. 


\title{
The acute toxicity of thallium to freshwater organisms: Implications for risk assessment
}

\author{
Kristi Tatsi ${ }^{\text {a }}$, Andrew Turner ${ }^{\text {b,* }}$, Richard D. Handy ${ }^{\text {a }}$, Benjamin J. Shaw ${ }^{\text {a }}$ \\ a School of Biological Sciences, Earth and Environmental Sciences, University of Plymouth, Drake Circus, Plymouth PL4 8AA, United Kingdom \\ b School of Geography, Earth and Environmental Sciences, University of Plymouth, Drake Circus, Plymouth PL4 8AA, United Kingdom
}

\section{H I G H L I G H T S}

- The toxicity of thallium to four freshwater organisms has been studied.

- The microalga, Pseudokirchneriella subcapitata, was most sensitive to Tl.

- Tl toxicity to Daphnia was greater in tap water than in artificial water.

- Various sub-lethal effects were observed in early-life stage Danio rerio.

- A PNEC for Tl of $0.087 \mu \mathrm{g} \mathrm{l}^{-1}$ is proposed.

\section{A R T I C L E I N F O}

\section{Article history:}

Received 20 April 2015

Received in revised form 18 June 2015

Accepted 18 June 2015

Available online $\mathrm{xxxx}$

Editor: D. Barcelo

\section{Keywords:}

Thallium

Toxicity

Freshwater organisms

Water quality guidelines

PNEC

Potassium

\begin{abstract}
A B S T R A C T
The acute toxicity of $\mathrm{Tl}(\mathrm{I})$ to the microalga, Pseudokirchneriella subcapitata, the planktonic crustaceans, Daphnia magna and Daphnia pulex, and early-life stage of the zebrafish, Danio rerio, has been studied according to OECD protocols. Toxicological end-point concentrations for the microalga ranged from $17 \mu g \mathrm{l}^{-1}$ for a $72 \mathrm{~h} \mathrm{E}_{\mathrm{y}} \mathrm{C}_{25}$ (yield inhibition) to $80 \mu \mathrm{g} \mathrm{l} \mathrm{l}^{-1}$ for a $72 \mathrm{~h} \mathrm{E}_{\mathrm{r}} \mathrm{C}_{50}$ (growth inhibition). Daphnia were less sensitive to Tl, with $48 \mathrm{~h}$ $\mathrm{EC}_{50} \mathrm{~S}$ of about $1000 \mu \mathrm{g} \mathrm{l^{-1 }}$ and $1200 \mu \mathrm{g} \mathrm{l^{-1 }}$ for D. magna and D. pulex, respectively; however, end-point concentrations were reduced considerably (to about $510 \mu \mathrm{g} \mathrm{l}^{-1}$ and $730 \mu \mathrm{g} \mathrm{l^{-1 }}$, respectively) when experiments were repeated in dechlorinated Plymouth tap water (rather than OECD medium). The $96 \mathrm{~h} \mathrm{LC}_{50}$ for $D$. rerio was $870 \mu \mathrm{g}^{-1}$ but a variety of sub-lethal effects, including enlargement of yolk sac and reduction in heart beat rate, were observed when larvae were exposed to lower concentrations. Based on these results, a predicted no effect concentration (PNEC) for Tl in freshwaters of $0.087 \mu \mathrm{g} \mathrm{l}^{-1}$ is proposed. The PNEC is an order of magnitude lower than the only (Canadian) water quality guideline for Tl that appears to exist, and is lower than $\mathrm{Tl}$ concentrations reported in freshwaters impacted by historical or contemporary metal mining. Our results are also consistent with previous studies that employ different organisms and end-points in that Tl toxicity is dependent on the concentration of $\mathrm{K}^{+}$, the biogeochemical analogue of $\mathrm{Tl}^{+}$. Accordingly, regulation of $\mathrm{Tl}$ in the freshwater environment should factor in the relative abundance of $\mathrm{K}$.
\end{abstract}

(c) 2015 Elsevier B.V. All rights reserved.

\section{Introduction}

Thallium is a non-essential, highly toxic heavy metal. Forming salts with both monovalent [thallous (I)] and trivalent [thallic (III)] oxidation states, it has a variety of properties and characteristics. Thus, Tl is very similar to $\mathrm{Pb}$ in terms of gravity, hardness, appearance, melting point and electrical conductivity (Galvan-Arzate and Santamaria, 1998). However, $\mathrm{Tl}^{+}$shares many characteristics with the alkali metals and is considered to be biogeochemically very similar to the potassium ion, $\mathrm{K}^{+}$(Kaplan and Mattigod, 1998; Hassler et al., 2007).

\footnotetext{
* Corresponding author.

E-mail address: aturner@plymouth.ac.uk (A. Turner).
}

Thallium is a relatively rare metal with an average concentration in the lithosphere of $1 \mu \mathrm{g} \mathrm{g}^{-1}$ (Smith and Carson, 1977). Although several Tl-bearing minerals exist, the metal is encountered mainly in minerals of potassium, such as alkali feldspars and micas, in coal, and in sulphides. Consequently, $\mathrm{Tl}$ is usually recovered for use in various specialist industries as a byproduct from flue dusts and residues resulting from the smelting and refining of sulphidic ores. As a contaminant, Tl enters the environment largely from the burning of coal and from metal mining and smelting (Peter and Viraraghavan, 2005).

Although $\mathrm{Tl}$ is more acutely toxic to mammals than $\mathrm{Cu}, \mathrm{Hg}, \mathrm{Cd}, \mathrm{Pb}$ and $\mathrm{Zn}$ (Cheam, 2001), there are relatively few studies that address its accumulation and effects in aquatic organisms. This is, perhaps, surprising since in many environments, and in particular those impacted by historical and contemporary metal mining, concentrations of aqueous 
Tl often exceed concentrations of other heavy metals, like $\mathrm{Cd}$ and $\mathrm{Pb}$, whose toxicities are much better defined (Tatsi and Turner, 2014). An examination of the literature reveals that, in fresh water and according to a variety of end points in a range of organisms, $\mathrm{Tl}(\mathrm{I})$ toxicity ranges from a few $\mu \mathrm{g}^{-1}$ to a few $\mathrm{mg} \mathrm{l}^{-1}$ (Zitko et al., 1975; Kwan and Smith, 1988; Borgmann et al., 1998; Pickard et al., 2001; Lin et al., 2005; Hassler et al., 2007; Rickwood et al., 2015). Toxic concentrations appear to be reduced in the presence of competitive ions, and in particular $\mathrm{K}^{+}$, the biogeochemical analogue of $\mathrm{Tl}^{+}$, but not by natural or artificial complexants, such as humic acids and EDTA (Zitko et al., 1975; Borgmann et al., 1998; Lustigman et al., 2000). Only one study appears to have completely isolated $\mathrm{Tl}(\mathrm{III})$ and addressed its toxicity (Ralph and Twiss, 2002); thus, while $\mathrm{Tl}^{3+}$ was found to be considerably more toxic than $\mathrm{Tl}^{+}$to the unicellular alga, Chlorella, the relative abundance of the thallic ion is predicted to be vanishingly low in most natural waters.

The Canadian Water Quality Guideline for total dissolved $\mathrm{Tl}$ is $0.8 \mu \mathrm{g} \mathrm{l}^{-1}$ (CCME, 1999). This guideline was derived from the chronic $(28 \mathrm{~d})$ toxicity of $\mathrm{Tl}(\mathrm{I})$ to the macrophyte, Lemna minor (Brown and Rattigan, 1979), the most sensitive aquatic organism and end-point reported at the time, coupled with a tenfold safety factor. Despite this quality standard, and the US recognising $\mathrm{Tl}$ as a priority pollutant, the metal is neither regulated in European waters nor considered as part of the Water Framework Directive (Commission of the European Communities, 2006).

The purpose of the present study was to assess the acute toxicity of $\mathrm{Tl}(\mathrm{I})$ to three key trophic species according to standardised OECD methods. To this end, we selected an algal growth test, the Daphnia immobilisation test and the fish, early-life test, and used end-points and timescales recognised for ecotoxicological hazard assessment. The results of the present investigation, together with those of previous studies, are used to re-evaluate the first tier of hazard assessment for $\mathrm{Tl}$ and propose refined water quality standards for the metal in the environment.

\section{Materials and methods}

Before being used in the experiments, all glassware was soaked in $5 \%$ $\mathrm{HNO}_{3}$ for $24 \mathrm{~h}$ and subsequently rinsed in Millipore Milli-Q water $(\mathrm{MQW} ; 18.2 \mathrm{M} \Omega \cdot \mathrm{cm})$. Working stock solutions of $\mathrm{Tl}(\mathrm{I})$ were prepared by diluting different quantities of a $10,000 \mathrm{mg} \mathrm{l}^{-1}$ Aristar solution of $\mathrm{Tl}$ in $0.5 \mathrm{M} \mathrm{HNO}_{3}$ (BDH Prolabo; CAS \# 7440-28-0) in a series of $100 \mathrm{ml}$ volumetric flasks using MQW. Test waters were prepared according to the appropriate OECD guidelines or by dechlorinating Plymouth tap water by bubbling air through 301 contained in a darkened polyethylene tank overnight. Unless otherwise stated, all other reagents used in the experiments and for sample processing or preservation were purchased from Fisher Scientific or Sigma-Aldrich.

\subsection{Algal growth inhibition test}

The algal growth inhibition test was conducted using a commercially available kit (Algaltoxkit FTM by MicroBioTests Inc., Belgium). The kit employs the microalga, Pseudokirchneriella subcapitata (product code CCAP278/4), and the test was performed following the standard operational procedure provided by the manufacturer and in accordance with the OECD 201 guideline (OECD, 2006). Briefly, tests were conducted at $23{ }^{\circ} \mathrm{C}$ in controlled temperature incubators under uniform illumination of 10,000 $\mathrm{lx}$ and using the $25 \mathrm{ml}$ cuvettes supplied with the kit. The growth medium was MQW amended with various salts, nutrients and EDTA and whose $\mathrm{pH}$ was adjusted to 8.1 by the addition of $\mathrm{NaOH}$ (and as monitored using a Hydrus 500 glass combination electrode). Cells were seeded at a density of $10,000 \mathrm{ml}^{-1}$ by measuring the turbidity of the medium at an absorbance of $670 \mathrm{~nm}$ using a 7315 spectrophotometer (Jenway Ltd, UK) against a standard curve of cell density provided with the Algaltoxkit FTM kit. Growth rate was determined daily over a period of $72 \mathrm{~h}$ using the same technique.

The experiment was performed in triplicate and using different concentrations of $\mathrm{Tl}$ obtained by diluting appropriate quantities of the various working stock solutions in algal culturing medium. Specifically, following an initial range-finding test, the exposures were conducted between $40 \mu \mathrm{g} \mathrm{l}^{-1}$ and $400 \mu \mathrm{g} \mathrm{l^{-1 }}$ and included a Tl-free control. The $\mathrm{pH}$ was monitored in the test cells at the beginning and end of the experiment and $5 \mathrm{ml}$ water samples were pipetted from each cuvette at the termination of the exposures into $10 \mathrm{ml}$ Sterilin tubes and acidified with $100 \mu \mathrm{l}$ of $\mathrm{HNO}_{3}$ pending analysis of $\mathrm{Tl}, \mathrm{Na}, \mathrm{K}$ and $\mathrm{Ca}$ by ICP (see below).

\subsection{Daphnia acute immobilisation test}

Given the paucity of acute toxicity data for $\mathrm{Tl}$ on invertebrates, experiments were conducted on two species of cladoceran, D. magna and D. pulex, according to OECD guideline 202 (OECD, 2004). Stocks of D. magna and D. pulex were purchased from Sciento (Manchester, UK) and were maintained in separate, $10 \mathrm{l}$ aquaria containing reconstituted OECD test water (MQW water amended with various salts) at $21{ }^{\circ} \mathrm{C}$ and under a $12 \mathrm{~h}$ fluorescent light: $12 \mathrm{~h}$ dark photoperiod for at least 2 weeks prior to use. Neonates were exposed in triplicate (with 30 animals per treatment) and for $48 \mathrm{~h}$ to $\mathrm{Tl}(\mathrm{I})$ concentrations ranging from 60 to $1200 \mu \mathrm{g} \mathrm{l}^{-1}$ (based on results of a range-finding test, data not shown) and to a Tl-free control in $40 \mathrm{ml}$ of OECD water in a series of $100 \mathrm{ml}$ plastic Galli pots under the culture conditions described above. Dissolved oxygen and $\mathrm{pH}$ were measured using a HACH HZ40d multi-meter with a glass combination electrode at the beginning and end of the exposures for the lowest and highest $\mathrm{Tl}$ concentrations employed. Five millilitre water samples were taken from each exposure vessel as above at the beginning and termination of all treatments for subsequent analysis of $\mathrm{Tl}$ and alkali metals.

Experiments were repeated using dechlorinated Plymouth tap water in order to establish whether $\mathrm{Tl}$ in natural water elicited a different response to $\mathrm{Tl}$ in the OECD medium. Here, animals were acclimatised in tap water and exposed to tap water amended with $\mathrm{Tl}$ under otherwise identical conditions to those described above.

\subsection{Fish, early-life stage toxicity test}

The early-life stage fish test was carried out following OECD 210 guidelines (OECD, 1992). Stocks of adult male and female zebrafish (Danio rerio) were placed together in a $20 \mathrm{l}$, aerated, flow-through glass tank containing dechlorinated tap water at $28 \pm 2{ }^{\circ} \mathrm{C}$ and under a photoperiod of $14 \mathrm{~h}$ fluorescent light: $10 \mathrm{~h}$ dark. Resulting embryos were collected approximately 30-60 min after spawning and carefully graded using a Kyowa Optical microscope (Model SDZ-PL; zoom HWF $10 \times)$. Viable embryos that were at the 8 -cell stage or beyond $(n=$ 360 ) were randomly selected for the exposures. Embryos were exposed in triplicate (with 20 embryos per treatment) and for $144 \mathrm{~h}$ to $\mathrm{Tl}$ (I) concentrations ranging from 50 to $800 \mathrm{~g} \mathrm{~g}^{-1}$ (established from a range-finding test, data not shown) and to a Tl-free control in $300 \mathrm{ml}$ of dechlorinated tap water in a series of $400 \mathrm{ml}$ Pyrex beakers under the culture conditions described above. A semi-static exposure method was adopted with $2 / 3$ of the water changed every $24 \mathrm{~h}$ with appropriate re-dosing (i.e. $2 / 3$ of the nominal dose). The number of dead and living embryos and/or larvae was counted by visual inspection or by optical microscope every $24 \mathrm{~h}$ and before each water change. The time of hatching and any abnormal behaviour or appearance were also noted. Water quality measurements were taken each day prior to water changes using a HACH HZ40d multi-meter. Five millilitre water samples for subsequent analysis of $\mathrm{Tl}$ and alkali metals were taken from each exposure vessel at the beginning, after every water change and at the end of all treatments. 
Table 1

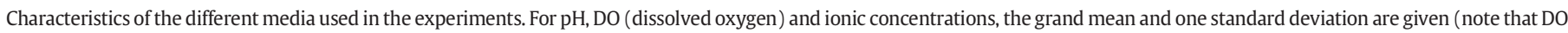
was not measured in the algal exposures).

\begin{tabular}{|c|c|c|c|c|c|c|c|c|}
\hline Organism & Medium & Temp. $\left({ }^{\circ} \mathrm{C}\right)$ & $\mathrm{pH}$ & $\mathrm{DO}\left(\mathrm{mg} \mathrm{l}^{-1}\right)$ & {$\left[\mathrm{Na}^{+}\right]\left(\mathrm{mg} \mathrm{l}^{-1}\right)$} & {$\left[\mathrm{K}^{+}\right]\left(\mathrm{mg} \mathrm{l}^{-1}\right)$} & {$\left[\mathrm{Ca}^{2+}\right]\left(\mathrm{mg} \mathrm{l}^{-1}\right)$} & {$\left[\mathrm{Mg}^{2+}\right]\left(\mathrm{mg} \mathrm{l}^{-1}\right)$} \\
\hline P. subcapitata & OECD 201 & 23 & $7.90 \pm 0.04$ & - & $30.2 \pm 0.9$ & $1.00 \pm 0.03$ & $8.9 \pm 0.1$ & $5.0 \pm 0.1$ \\
\hline \multirow[t]{2}{*}{ D. magna/D. pulex } & OECD 202 & 21 & $7.70 \pm 0.19$ & $8.23 \pm 0.05$ & $17.6 \pm 0.4$ & $3.00 \pm 0.08$ & $71.0 \pm 0.2$ & $11.0 \pm 0.1$ \\
\hline & Tap water & 21 & $7.60 \pm 0.23$ & $8.12 \pm 0.05$ & $11.1 \pm 0.3$ & $1.45 \pm 0.08$ & $25.0 \pm 0.3$ & $2.1 \pm 0.3$ \\
\hline D. rerio & Tap water & 28 & $7.50 \pm 0.16$ & $7.18 \pm 0.07$ & $6.2 \pm 0.1$ & $1.25 \pm 0.05$ & $16.5 \pm 0.1$ & $6.2 \pm 0.7$ \\
\hline
\end{tabular}

Morphometrics were measured on surviving larvae at the end of the experiment. Briefly, larvae were euthanized in $200 \mathrm{mg} \mathrm{l}^{-1}$ of buffered MS222 and then fixed in formalin. Larvae ( $n=4$ per beaker, $n=12$ per treatment) were photographed (at $1.6 \times$ and $4 \times$ magnification) using a Lumenera Infinity 2 digital camera attached to a Meiji binocular microscope and subsequent size measurements were undertaken manually using Image J 1.46r software. The length of the larvae and the width of the spinal cord muscle block were measured as growth indicators while the length $(L, \mathrm{~mm})$ and height $(H, \mathrm{~mm})$ of the yolk sac were measured to identify any changes in sac volume $\left(V, \mathrm{~mm}^{3}=6 / \pi L H^{2}\right)$ and as indicators of oedema (Velasco-Santamaría et al., 2011).

Because of the possibility that $\mathrm{Tl}$ toxicity may be mediated by interference with $\mathrm{K}^{+}$homeostasis, the heart beat rates of the fish were also measured during the experiment $\left(\mathrm{K}^{+}\right.$is essential for heart contractility). Measurements were conducted after an exposure period of $96 \mathrm{~h}$ on surviving larvae randomly selected from each beaker dosed with the highest concentration of $\mathrm{Tl}$ and from each beaker containing no added Tl. Individuals were placed in a small volume of dechlorinated tap water under a binocular microscope and heart beat rate was determined manually and in triplicate by recording the number of beats over $30 \mathrm{~s}$; larvae were then placed back into their beakers for the remaining period of the exposures.

\subsection{Metal analysis}

Thallium in water samples from the experiments and in a certified reference material (Drinking Water 904020, Charleston, SC; $\mathrm{Tl}=10 \mu \mathrm{g} \mathrm{l}^{-1}$ ) were analysed using a Thermo Scientific X Series 2 II bench top quadrupole inductively coupled plasma-mass spectrometer (ICP-MS) with a collision cell according to operating conditions given in Turner et al. (2010). The instrument was calibrated using a blank and five standards in the range 10 to $1000 \mathrm{gg} \mathrm{l}^{-1}$ (prepared by serial dilution of the Prolabo Aristar standard in $0.3 \mathrm{M} \mathrm{HNO}_{3}$ ) and internal standardisation was achieved by the addition of $100 \mu \mathrm{g} \mathrm{l}^{-1}$ of ${ }^{193}$ Ir to all samples and standards. The relative standard deviation of replicate measurements of $\mathrm{Tl}$ in all samples was generally less than $10 \%$ and accuracy, based on analyses of the reference material, was better than 90\%. Limit of detection, based on $3 \sigma$ of multiple measurements of the lowest standard, was $6 \mathrm{ng} \mathrm{l}^{-1}$.

Ions essential for fish and invertebrate health and that may compete with $\mathrm{Tl}^{+}$at the cellular level $\left(\mathrm{Na}^{+}, \mathrm{K}^{+}, \mathrm{Ca}^{2+}, \mathrm{Mg}^{2+}\right)$ were analysed as their respective elements by ICP-optical emission spectrometry using a Varian 725-ES according to operating conditions outlined by Jessop and Turner (2011). The instrument was calibrated using five mixed standards and a blank prepared by serial dilution of Spectrosol plasma emission standards in $0.3 \mathrm{M} \mathrm{HNO}_{3}$.

\subsection{Data treatment and statistical analysis}

The percentage inhibition of both specific growth rate $\left(E_{r} C_{x}\right.$, based on the logarithmic increase of biomass during the test period) and yield $\left(\mathrm{E}_{\mathrm{y}} \mathrm{C}_{\mathrm{x}}\right.$, based on the biomass at the end of the test minus the starting biomass) were calculated after treatment of data according to OECD guideline 201 (OECD, 2006). The effect concentrations to $50 \%$ and $25 \%$ of the population of Daphnia at $48 \mathrm{~h}\left(\mathrm{EC}_{50}\right.$ and $\mathrm{EC}_{25}$, respectively) were estimated by fitting a sigmoid curve to the data using Sigma Plot $v 12.5$. Likewise, and regarding zebrafish, the lethal concentrations to $50 \%$ and $25 \%$ of the population at a specific time ( $\mathrm{LC}_{50}$ and $\mathrm{LC}_{25}$, respectively) and the lethal time to $50 \%$ of the population for a given concentration $\left(\mathrm{LT}_{50}\right)$ were estimated by sigmoid curve-fitting.

Following tests for unequal variance (Bartlett's test), one way analysis of variance (ANOVA) was used to determine the statistical significance of differences in water quality parameters between tests and among replicates, and differences in zebrafish morphometric data arising from the different treatments. All statistical analyses were performed using StatGraphics Centurion XVI.I and used a rejection level criterion of $p<0.05$.

\section{Results}

\subsection{Water characteristics and confirmation of Tl exposure}

The physico-chemical characteristics of the waters used in the experiments are shown in Table 1 . For $\mathrm{pH}$, dissolved oxygen and concentrations of the alkali metal ions, the grand mean and standard deviation arising from replicate measurements taken at multiple times and/or multiple ( $\mathrm{Tl}$ ) exposure concentrations are shown. For a given experiment, no statistically significant differences in water characteristics were observed during the time course or between different exposures. Note, however, that the composition of tap water (and in particular concentrations of $\mathrm{Na}$ and $\mathrm{Mg}$ ) was different on the two occasions used for the exposures. Note also that the concentration of dissolved organic carbon in tap water, although not measured directly, averages about $0.8 \mathrm{mg} \mathrm{l}^{-1}$ for the region according to local water authority data.

In all cases, concentrations of $\mathrm{Tl}$ measured throughout the experiments did not deviate substantially from nominal (added) concentrations. This is exemplified by plots of measured versus nominal

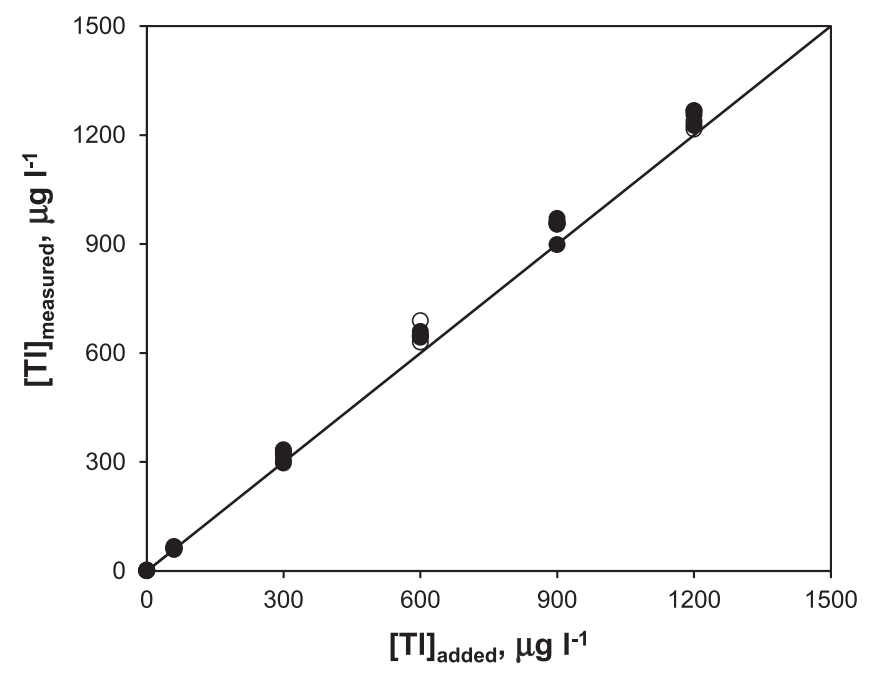

Fig. 1. Concentrations of measured $\mathrm{Tl}$ versus concentrations of added $\mathrm{Tl}$ at the beginning (O) and end ( $48 \mathrm{~h}$; ) of the exposures to D. magna in OECD water. Note, the solid line represents unit slope. 


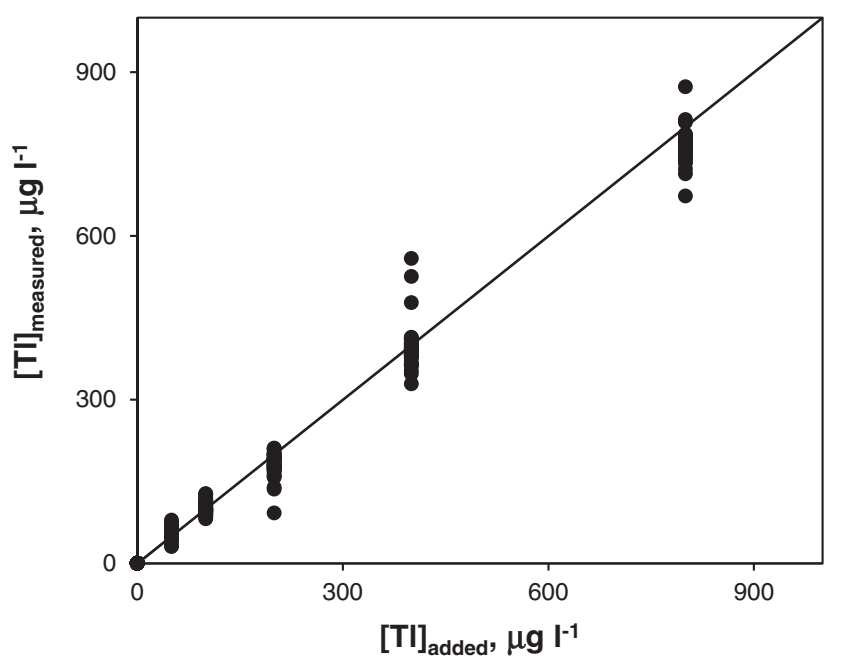

Fig. 2. Concentrations of measured $\mathrm{Tl}$ versus concentrations of added $\mathrm{Tl}$ at the beginning, at each water change and at the end $(144 \mathrm{~h})$ of the exposures to $D$. rerio in Plymouth tap water. Note, the solid line represents unit slope.

concentrations in the experiment in which $D$. magna were exposed to a single addition of $\mathrm{Tl}$ in OECD medium (Fig. 1 ) and $D$. rerio were exposed to $\mathrm{Tl}$ added to dechlorinated tap water that was replenished on a daily basis (Fig. 2). The results indicate that, during the experiments, Tl was not subject to significant inputs from (cross) contamination or to significant loss through, for example, precipitation or instantaneous or progressive adsorption to container surfaces.

\subsection{Algal growth inhibition test}

Results of the growth inhibition test in which P. subcapitata was exposed to variable $\mathrm{Tl}(\mathrm{I})$ concentrations in OECD medium are shown in terms of algal cell density in Fig. 3, and estimated toxic concentrations for the different end-points are shown in Table 2. The biomass increased exponentially by a factor of $>16$ in the controls, in agreement with the validation conditions of the test guidelines, and Tl reduced algal density by more than $50 \%$ at a concentration of $40 \mu \mathrm{g} \mathrm{l^{-1 }}$ and by more than $95 \%$ at concentrations at and above $128 \mu \mathrm{g} \mathrm{l}^{-1}$; complete inhibition of growth rate occurred at the two highest concentrations of Tl employed.

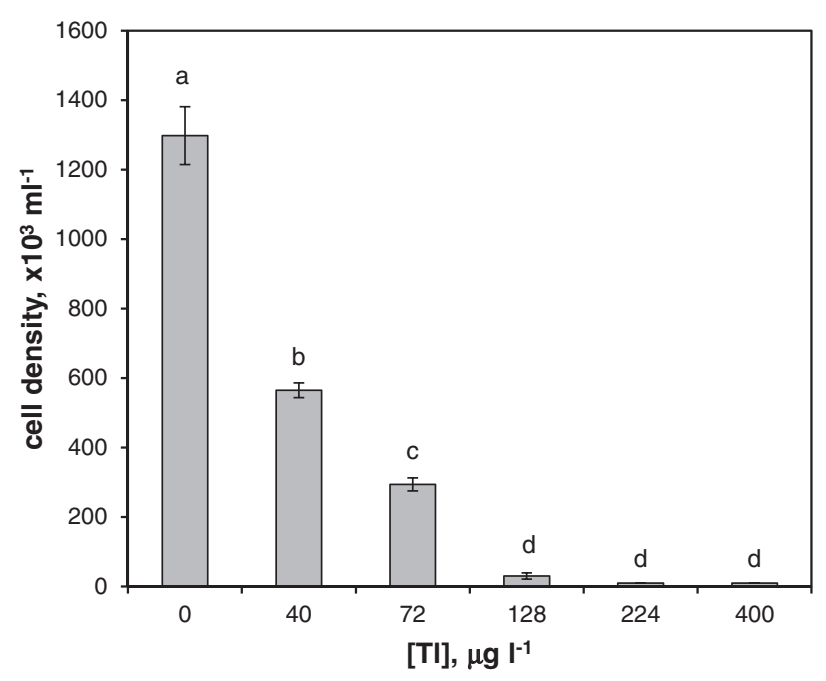

Fig. 3. Cell density of $P$. subcapitata as a function of nominal $\mathrm{Tl}$ concentration and as determined at the end of the $72 \mathrm{~h}$ exposure. Errors denote one standard deviation about the mean and different letters denote significant differences among treatments (ANOVA, $p<0.05)$.
Table 2

Estimated toxic concentrations of $\mathrm{Tl}(\mathrm{I})$ to the four organisms and for the different endpoints.

\begin{tabular}{llcc}
\hline Organism & Medium & End-point & {$[\mathrm{Tl}(\mathrm{I})], \mu \mathrm{g} \mathrm{l}^{-1}$} \\
\hline P. subcapitata & OECD 201 & $72 \mathrm{~h} \mathrm{E}_{\mathrm{r}} \mathrm{C}_{50}$ & 87 \\
& & $72 \mathrm{~h} \mathrm{E}_{\mathrm{y}} \mathrm{C}_{50}$ & 33 \\
& & $72 \mathrm{~h} \mathrm{E}_{\mathrm{r}} \mathrm{C}_{25}$ & 40 \\
& & $72 \mathrm{~h} \mathrm{E}_{\mathrm{y}} \mathrm{C}_{25}$ & 17 \\
D. magna & $48 \mathrm{~h} \mathrm{EC}_{50}$ & 1180 \\
& OECD 202 & $48 \mathrm{~h} \mathrm{EC}_{25}$ & 750 \\
& & $48 \mathrm{~h} \mathrm{EC}_{50}$ & 510 \\
& Tap water & $48 \mathrm{~h} \mathrm{EC}_{25}$ & 350 \\
& & $48 \mathrm{~h} \mathrm{EC}_{50}$ & 980 \\
O. pulex & OECD 202 & $48 \mathrm{~h} \mathrm{EC}_{25}$ & 740 \\
& & $48 \mathrm{~h} \mathrm{EC}_{50}$ & 725 \\
& Tap water & $48 \mathrm{~h} \mathrm{EC}_{25}$ & 580 \\
& & $96 \mathrm{~h} \mathrm{LC}_{50}$ & 870 \\
D. rerio & Tap water & $144 \mathrm{~h} \mathrm{LC}_{50}$ & 290 \\
& & $144 \mathrm{~h} \mathrm{LC}_{25}$ & 160 \\
\hline
\end{tabular}

From the inhibition results, values for $72 \mathrm{~h}_{\mathrm{r}} \mathrm{C}_{50}$ and $\mathrm{E}_{\mathrm{y}} \mathrm{C}_{50}$ were estimated to be $87 \mu \mathrm{gl}^{-1}$ and $33 \mu \mathrm{g} \mathrm{l^{-1 }}$, respectively, while values for $72 \mathrm{~h} \mathrm{E}_{\mathrm{r}} \mathrm{C}_{25}$ and $\mathrm{E}_{\mathrm{y}} \mathrm{C}_{25}$ were estimated to be around $40 \mu \mathrm{g} \mathrm{l}^{-1}$ and $17 \mu \mathrm{g} \mathrm{l}^{-1}$, respectively. Repeating the experiment using concentrations of $\mathrm{Tl}$ in the range 10 to $100 \mu \mathrm{g} \mathrm{l^{-1 }}$ allowed us to establish a NOEC of less than $10 \mu \mathrm{g} \mathrm{l^{-1 }}$.

\subsection{Daphnia immobilisation test}

The effects of increasing $\mathrm{Tl}(\mathrm{I})$ concentration on the immobility of the cladocerans, D. magna and D. pulex, are shown in Fig. 4, and estimated toxic concentrations for the various end-points are shown in Table 2. Immobility was $0 \%$ in all controls and increased with increasing $\mathrm{Tl}$ concentration in each case but at different rates. Regarding D. magna, estimated values of $48 \mathrm{~h} \mathrm{EC}_{50}$ and $\mathrm{EC}_{25}$ in dechlorinated tap water were $510 \mu \mathrm{g}^{-1}$ and $350 \mu \mathrm{g} \mathrm{l}^{-1}$, respectively. In OECD water, the respective values were $1180 \mathrm{gg}^{-1}$ and $750 \mu \mathrm{g} \mathrm{l} \mathrm{l}^{-1}$ and greater than the corresponding values in tap water; the NOEC was less than $60 \mu \mathrm{g} \mathrm{l^{-1 }}$ in tap water and between $60 \mu \mathrm{g} \mathrm{l}^{-1}$ and $300 \mu \mathrm{g} \mathrm{l^{-1 }}$ in the OECD medium. With respect to D. pulex, estimated values of $48 \mathrm{~h} \mathrm{EC}_{50}$ and $\mathrm{EC}_{25}$ in tap water were $725 \mu \mathrm{g} \mathrm{l}^{-1}$ and $580 \mu \mathrm{g} \mathrm{l^{-1 }}$, respectively, while in OECD water the respective values were $980 \mu \mathrm{g} \mathrm{l}^{-1}$ and $740 \mu \mathrm{g} \mathrm{l}{ }^{-1}$; the NOEC was between $60 \mu \mathrm{g} \mathrm{l^{-1 }}$ and $300 \mu \mathrm{g} \mathrm{l^{-1 }}$ in both media.

\subsection{Fish, early-life stage toxicity test}

The results of the tests performed on D. rerio are shown in Fig. 5 and estimated toxic concentrations for the different end-points are presented in Table 2. Cumulative survival is shown on a daily basis and cumulative mortality is shown at the termination of the experiment (144 h). In the Tl-free control, survival remained reasonably constant at about 95\% (5\% mortality represents a typical background level), while in the presence of $\mathrm{Tl}(\mathrm{I})$ a concentration-dependent response was observed once embryos had hatched. The $\mathrm{LC}_{50}$ at $96 \mathrm{~h}$ was estimated to be $870 \mu \mathrm{g} \mathrm{l^{-1 }}$ while the $\mathrm{LC}_{50}$ and $\mathrm{LC}_{25}$ at $144 \mathrm{~h}$ were about $290 \mu \mathrm{g} \mathrm{l^{-1 }}$ and $160 \mu \mathrm{g} \mathrm{l}^{-1}$, respectively. For the highest exposure concentration $\left(800 \mu \mathrm{g} \mathrm{l}^{-1}\right)$, the time to attain $50 \%$ lethality $\left(\mathrm{LT}_{50}\right)$ was about $100 \mathrm{~h}$ (4.2 days), and the NOEC at the termination of the experiment was less than $50 \mu \mathrm{g} \mathrm{l}^{-1}$.

To assess the sub-lethal effects of $\mathrm{Tl}$ on $D$. rerio, the total length of the larvae, width of the spinal cord muscle block and volume of the yolk sac were measured in animals surviving at the end of the exposures. Although there were no statistical differences in larval lengths among the treatments, yolk sac volume increased with increasing exposure concentration up to $400 \mu \mathrm{g} \mathrm{l} \mathrm{l}^{-1}$, or the highest concentration at which larvae survived (Fig. 6a); successive increases in yolk sac volume were not, however, always significant. When exposed to $\mathrm{Tl}$, spinal cord 

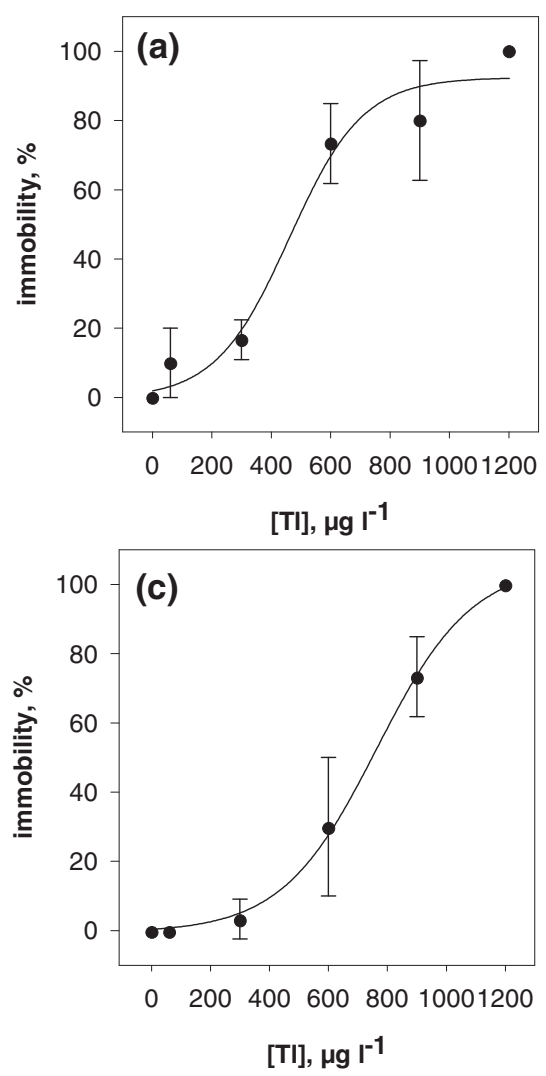
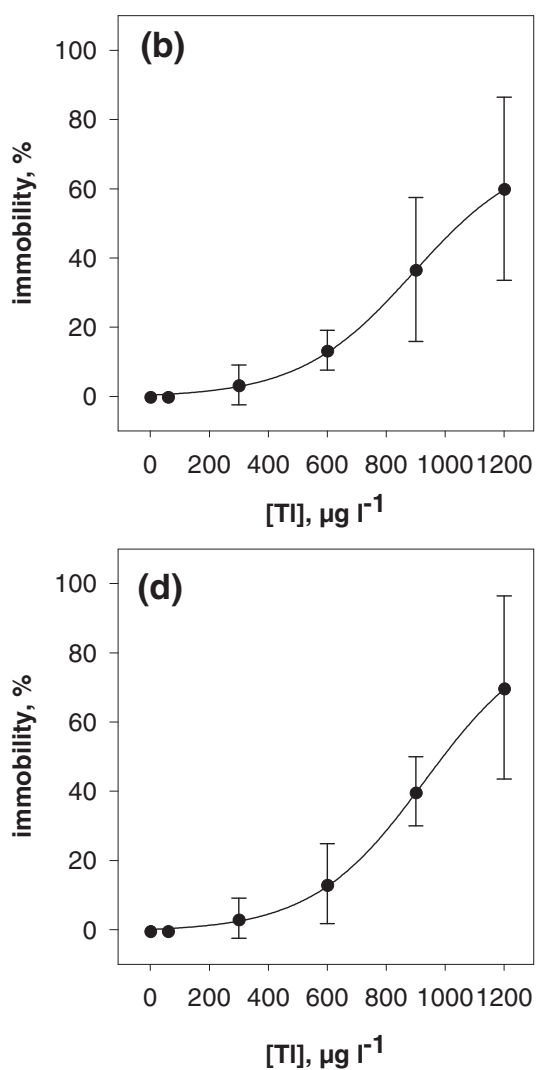

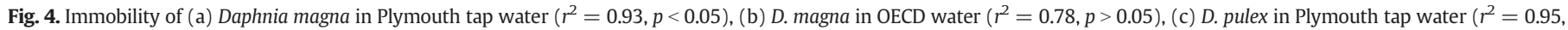
$p<0.05)$ and $(\mathrm{d})$ D. pulex in OECD water $\left(r^{2}=0.86, p<0.05\right)$ after $48 \mathrm{~h}$ exposure to different nominal concentrations of Tl. Errors denote one standard deviation about the mean.

muscle block width exhibited a significant increase relative to the control animals (Fig. 6b), although successive increases in $\mathrm{Tl}$ concentration did not result in any significant successive differences in width. After $96 \mathrm{~h}$, larvae exposed to $800 \mu \mathrm{g} \mathrm{l^{-1 }}$ appeared moribund and their heart beat rates ( $64 \pm 4$ per minute) were about $65 \%$ lower than rates for control larvae ( $216 \pm 1$ per minute).

In addition to the measurements above, imaging revealed enlarged pericardial areas, indicative of oedema, and a shortened snout (Fig. 6d), indicative of abnormal growth development. There were no concentration-dependent differences in hatching success of exposed animals, although a non-significant trend of increased time to hatch with increasing $\mathrm{Tl}$ concentration was noted (data not shown).

\section{Discussion}

\subsection{Comparison of $\mathrm{Tl}$ toxicity with literature data}

This study is one of relatively few to examine the toxicity of $\mathrm{Tl}$ to freshwater organisms. Specifically, it is the first to address the acute toxicity of $\mathrm{Tl}(\mathrm{I})$ to three trophic levels according to recognised (OECD) guidelines, the first to evaluate toxicity to two important test organisms (namely, D. pulex and D. rerio), and the first to examine sub-lethal effects on early-life stage fish. It is also one of very few studies in which Tl concentrations have been monitored throughout the exposures and controls.

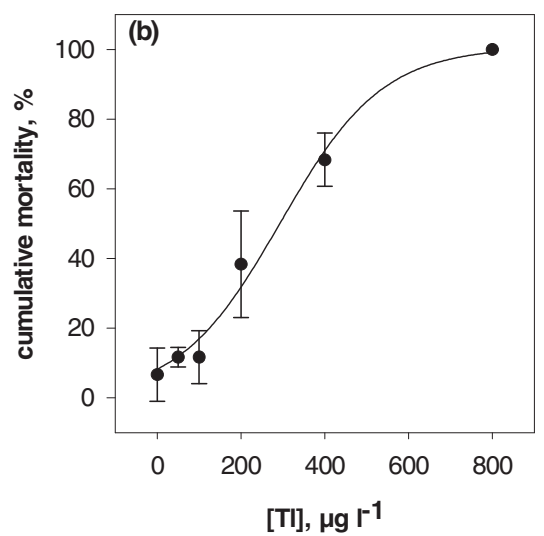

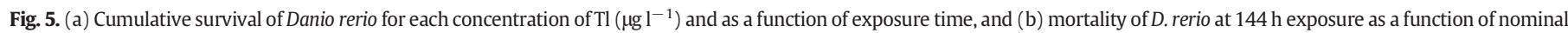
Tl concentration $\left(r^{2}=0.98 ; p<0.05\right)$. Errors denote one standard deviation about one mean. 

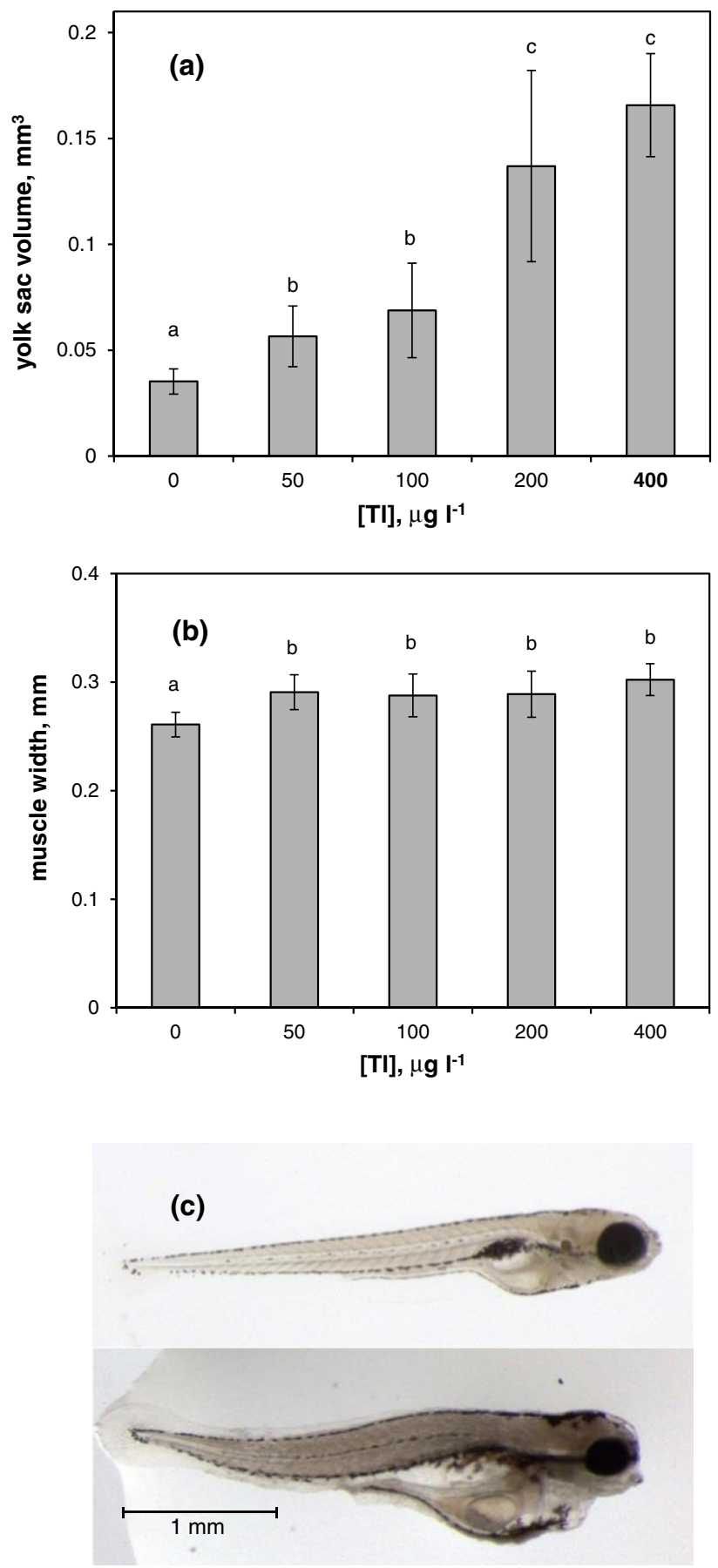

Fig. 6. Sub-lethal effects on $D$. rerio larvae exposed to Tl for $144 \mathrm{~h}$ : (a) Yolk sac volume and (b) spinal cord muscle width, where errors denote one standard deviation about the mean $(n=12)$ and different letters denote significant differences among treatments (ANOVA, $p<0.05$ ), and (c) images of a control larva (above) and a larva exposed to $400 \mu \mathrm{gl}^{-1} \mathrm{Tl}$ (below).

To put the results of this study into context, Table 3 compares the toxicities of $\mathrm{Tl}(\mathrm{I})$ to freshwater primary producers, invertebrates and fish as reported in the literature and where comparable end-points (e.g. $\mathrm{EC}_{\mathrm{x}}, \mathrm{LC}_{\mathrm{x}}, \mathrm{IC}_{\mathrm{x}}$ ) are provided. Note that additional studies on $\mathrm{Tl}(\mathrm{I})$ toxicity in fresh waters, including those on bacteria and fungi or older studies where end-points are not always defined or quantified, have been reviewed by the EPA (1980) and Couture et al. (2011). Overall, our results are within the range of $\mathrm{Tl}$ concentrations reported in Table 3 that elicit a toxic response. More specifically, the lowest and highest concentrations we observed to be toxic to P. subcapitata ( $72 \mathrm{~h}$
$\mathrm{E}_{\mathrm{y}} \mathrm{C}_{25}=17 \mu \mathrm{g} \mathrm{l}^{-1} ; 72 \mathrm{~h} \mathrm{E}_{\mathrm{r}} \mathrm{C}_{50}=87 \mu \mathrm{g} \mathrm{l^{-1 }}$ ) are within an order of magnitude of independent results attained using the same microalga ( $72 \mathrm{~h}$ $\mathrm{IC}_{25}=90 \mu \mathrm{g} \mathrm{l}^{-1}$ and $160 \mu \mathrm{g} \mathrm{l} \mathrm{l}^{-1}$ ) and using Chlorella sp. (72 $\mathrm{h} \mathrm{EC} 50$ $160 \mu \mathrm{g} \mathrm{l}^{-1}$ ). With respect to Daphnia, our range of toxic concentrations ( $48 \mathrm{~h} \mathrm{EC}_{25}=350 \mu \mathrm{g} \mathrm{l}^{-1} ; 48 \mathrm{~h} \mathrm{EC}_{50}=1180 \mu \mathrm{g} \mathrm{l}^{-1}$ ) is quantitatively similar to the concentration range reported in the literature for the survival of water fleas ( $168 \mathrm{~h} \mathrm{LC}_{50}$ for Ceriodaphnia dubia $=370 \mu \mathrm{g} \mathrm{I}^{-1} ; 48 \mathrm{~h} \mathrm{LC}_{50}$ for $D$. magna $\left.=2010 \mu \mathrm{g} \mathrm{l}^{-1}\right)$. Regarding early-life stage fish, our lowest and highest toxic concentrations ( $144 \mathrm{~h} \mathrm{LC}_{25}=162 \mu \mathrm{g} \mathrm{l}^{-1}$; $96 \mathrm{~h} \mathrm{LC}_{50}=$ $870 \mu \mathrm{g} \mathrm{l}^{-1}$ ) compare with a $96 \mathrm{~h} \mathrm{LC}_{50}$ and $168 \mathrm{~h} \mathrm{LC}_{50}$ for Pimephales promelas (fathead minnow) of $860 \mu \mathrm{g} \mathrm{l} \mathrm{l}^{-1}$ and $>500 \mu \mathrm{g} \mathrm{l^{-1 }}$, respectively.

The end-point concentrations derived in the present study, coupled with a NOEC of less than $10 \mu \mathrm{g} \mathrm{l} \mathrm{l}^{-1}$ for P. subcapitata, would suggest that microalgae, at the base of the food web, are more sensitive to Tl than either invertebrates or fish. However, inspection of the results in Table 3 reveals toxicities of less than $10 \mu \mathrm{g}^{-1}$ for both the amphipod, Hyalella azteca, and the macroalga, L. minor, in addition to a $30 \mu \mathrm{g} \mathrm{l}^{-1}$ "incipient", $108 \mathrm{~d}$, lethal toxicity to juvenile Atlantic salmon, Salmo salar, mentioned by Zitko et al. (1975). Our study has also demonstrated important sublethal effects to fish larvae exposed to a Tl concentration of $50 \mu \mathrm{g} \mathrm{l}^{-1}$ (enlargement of the yolk sac) and a significant impact on the heart, a vital organ, at the only exposure concentration tested $\left(800 \mu \mathrm{g} \mathrm{l}^{-1}\right)$. The latter observation is of particular concern and could be related to or the result of yolk sac and pericardial oedema. Alternatively or additionally, the reduction in heart beat rate could be due to $\mathrm{Tl}^{+}$replacing the $\mathrm{K}^{+}$required for muscle contraction (Galvan-Arzate and Santamaria, 1998).

\subsection{Thallium toxicity compared with other metal toxicities}

In order to compare the fresh water acute toxicity of $\mathrm{Tl}(\mathrm{I})$ with the toxicities of other metals, results from the same tests and that employ identical end-points need to be considered. To this end, our end-point concentrations are compared with results from independent studies that have used the same tests but different metals in Fig. 7, while other studies that include $\mathrm{Tl}$ among a suite of other metals in specific toxicity tests are shown in Fig. 8. The comparisons reveal that, of the metals studied, and on a weight-concentration basis and neglecting speciation (and in particular, the relative abundance of the free ion), $\mathrm{Tl}$ is least toxic to microalgae ( $P$. subcapitata and Chlamydomonas reinhardtii), most toxic to macrophytes (L. minor and Elodea canadensis, but not the clone of the former), and of intermediate toxicity to invertebrates (D. magna and H. Azteca) and early-life stage fish (D. rerio). On a molar basis the trends are similar, except that $\mathrm{Tl}$ is more toxic than $\mathrm{Cd}$, $\mathrm{Cu}$ and $\mathrm{Ni}$ to the clone of $\mathrm{L}$. minor, more toxic than $\mathrm{Cu}$ to $C$. reinhardtii, and more toxic than $\mathrm{Cd}$ and $\mathrm{Zn}$ to P. subcapitata.

\subsection{Dependence of $T l$ toxicity on water chemistry}

The physico-chemical characteristics of the aqueous medium usually have a significant impact on the toxicity of metals through both speciation and the abundance of competing ions. Equilibrium speciation calculations performed by Kaplan and Mattigod (1998) and Turner et al. (2010) suggest that, in natural fresh waters, the majority of $\mathrm{Tl}(\mathrm{I})$ occurs as $\mathrm{Tl}^{+}$, and that in the absence of appreciable quantities of organic matter the relative abundance of the free ion is likely to approach $100 \%$. With respect to artificial media, $\mathrm{Tl}(\mathrm{I})$ has a relatively low affinity for chelators that are often added, like EDTA (e.g. $\log K$ Tl-EDTA $^{3-}=7.3 \mathrm{cf} \log K \mathrm{Cu}$-EDTA ${ }^{2-}=20.5$; Couture et al., 2011). Thus, it would be reasonable to assume that in both OECD media and Plymouth tap water, the concentrations of $\mathrm{Tl}$ that are toxic in the present study apply to both total metal and the free ion (i.e. $[\mathrm{Tl}(\mathrm{I})]=\left[\mathrm{Tl}^{+}\right]$); this assumption is also likely to be valid for the results of the independent studies presented in Table 3.

Regarding competing ions, the concentration of $\mathrm{K}^{+}$is particularly important to $\mathrm{Tl}^{+}$toxicity because of similarities in their ionic and 
Table 3

Details and results of published studies on $\mathrm{Tl}(\mathrm{I})$ toxicity to fresh water primary producers, invertebrates and fish.

\begin{tabular}{|c|c|c|c|c|c|}
\hline Tl added & Species & Medium & Measure; end point & Toxicity, $\mu \mathrm{g} \mathrm{l}^{-1}$ & Reference \\
\hline & Microalgae & & & & \\
\hline Not specified & Chlamydomonas reinhardtii & Buffered distilled water & $\mathrm{O}_{2}$ evolution; $\mathrm{IC}_{50}$ (time unspecified) & 3060 & Overnell (1975) \\
\hline Not specified & Pseudokirchneriella subcapitata & Not specified & Growth; 72 h IC 25 & 90 & Pickard et al. (2001) \\
\hline \multirow[t]{2}{*}{$\mathrm{Tl}(\mathrm{I}) \mathrm{NO}_{3}$} & \multirow[t]{2}{*}{ Pseudokirchneriella subcapitata } & M4 & Growth; 72 h IC 25 & 160 & \multirow[t]{2}{*}{ Rickwood et al. (2015) } \\
\hline & & M4 without $\mathrm{K}^{+}$ & Growth; 72 h IC 25 & 4.6 & \\
\hline \multirow[t]{3}{*}{$\mathrm{Tl}(\mathrm{I})$ standard } & \multirow[t]{2}{*}{ Chlorella sp. } & Fraquil & Growth; 72 h EC 50 & 160 & \multirow[t]{2}{*}{ Hassler et al. (2007) } \\
\hline & & Fraquil without $\mathrm{K}^{+}$ & Growth; 72 h EC 50 & 2.0 & \\
\hline & Macrophytes & & & & \\
\hline \multirow{2}{*}{$\mathrm{Tl}(\mathrm{I})_{2} \mathrm{SO}_{4}$} & Elodea canadensis & Buffered distilled water & Plant damage; $28 \mathrm{~d} \mathrm{IC}_{50}$ & 2000 & \multirow{2}{*}{ Brown and Rattigan (1979) } \\
\hline & Lemna minor & Buffered distilled water & Plant damage; $28 \mathrm{~d} \mathrm{IC}_{50}$ & 8 & \\
\hline $\mathrm{Tl}(\mathrm{I}) \mathrm{NO}_{3}$ & Lemna minor L. clone St & Steinberg & Various growth parameters; $168 \mathrm{~h} \mathrm{EC}_{50}$ & $\sim 300$ & Naumann et al. (2007) \\
\hline $\mathrm{Tl}(\mathrm{I}) \mathrm{NO}_{3}$ & Lemna minor L. clone St & Steinberg & Frond abscission; $24 \mathrm{~h} \mathrm{E} \mathrm{F}_{\mathrm{FA}} \mathrm{C}_{50}$ & 440 & Henke et al. (2011) \\
\hline $\mathrm{Tl}(\mathrm{I}) \mathrm{CH}_{3} \mathrm{OO}$ & Lemna minor & 1/4 Steinberg & Growth/frond no.; $10 \mathrm{~d} \mathrm{EC}_{50}$ & 32 to 47 & Kwan and Smith (1988) \\
\hline \multirow{5}{*}{$\mathrm{Tl}(\mathrm{I}) \mathrm{NO}_{3}$} & \multirow{5}{*}{$\begin{array}{l}\text { Invertebrates } \\
\text { Hyalella azteca }\end{array}$} & & & & \\
\hline & & Dechlorinated tap water & Survival; $28 \mathrm{~d} \mathrm{LC}_{25}$ & 10 & \multirow[t]{4}{*}{ Borgmann et al. (1998) } \\
\hline & & Dechlorinated tap water & Growth; $42 \mathrm{~d} \mathrm{EC}_{25}$ & 7.1 & \\
\hline & & Artificial medium without $\mathrm{K}^{+}$ & Survival; $28 \mathrm{~d} \mathrm{LC}_{25}$ & 2.4 & \\
\hline & & Artificial medium without $\mathrm{K}^{+}$ & Growth; $42 \mathrm{~d} \mathrm{EC}_{25}$ & 1.8 & \\
\hline \multirow[t]{2}{*}{$\mathrm{Tl}(\mathrm{I}) \mathrm{NO}_{3}$} & Daphnia magna & EPA “moderately" hard water & Survival; $48 \mathrm{~h} \mathrm{EC}_{50}$ & 1660 & \multirow[t]{2}{*}{ Lin et al. (2005) } \\
\hline & Ceriodaphnia dubia & EPA "moderately" hard water & Survival; $48 \mathrm{~h} \mathrm{EC} 50$ & 660 & \\
\hline \multirow[t]{3}{*}{ Not specified } & Daphnia magna & Not specified & Survival; 48 h LC 50 & 2010 & \multirow[t]{3}{*}{ Pickard et al. (2001) } \\
\hline & Ceriodaphnia dubia & Not specified & Survival; $168 \mathrm{~h} \mathrm{LC}_{50}$ & 370 & \\
\hline & Ceriodaphnia dubia & Not specified & Reproduction; 168 h IC 25 & 100 & \\
\hline \multirow[t]{3}{*}{$\mathrm{Tl}(\mathrm{I}) \mathrm{NO}_{3}$} & Ceriodaphnia dubia & M4 & Neonate production; $<144 \mathrm{~h} \mathrm{IC}_{25}$ & 160 & \multirow[t]{2}{*}{ Rickwood et al. (2015) } \\
\hline & & M4 without $\mathrm{K}^{+}$ & Neonate production; $<144 \mathrm{~h} \mathrm{IC}_{25}$ & 35 & \\
\hline & Fish & & & & \\
\hline $\mathrm{Tl}(\mathrm{I})_{2} \mathrm{SO}_{4}$ & Pimephales promelas larvae & Well water & Survival; 96 h LC 50 & 860 & LeBlanc and Dean (1984) \\
\hline $\mathrm{Tl}(\mathrm{I}) \mathrm{NO}_{3}$ & Pimephales promelas larvae & Dechlorinated tap water & Survival; 168 LC $_{50}$ & $>500$ & Rickwood et al. (2015) \\
\hline Not specified & Oncorhynchus mykiss & Not specified & Survival; 96 h LC 50 & 4270 & Pickard et al. (2001) \\
\hline
\end{tabular}

consequent similarities in their biogeochemical characteristics and behaviours at the cellular level (Brismar, 1998). Thus, $\mathrm{K}^{+}$has been observed to reduce both the uptake and toxicity of $\mathrm{Tl}(\mathrm{I})$ in a range of aquatic organisms (Borgmann et al., 1998; Twiss et al., 2004; Hassler et al., 2007; Rickwood et al., 2015) and differences in its concentration among different media likely account for variations in $\mathrm{Tl}(\mathrm{I})$ toxicity observed for a given species (see results in Table 3). In the present study, evidence for the ameliorating role of $\mathrm{K}^{+}$on $\mathrm{Tl}$ toxicity is observed in the results of the Daphnia exposures conducted in OECD water and dechlorinated tap water. Here, Tl is more toxic to both species in tap water because its $\mathrm{K}$ concentration is about half of that in the synthetic medium.

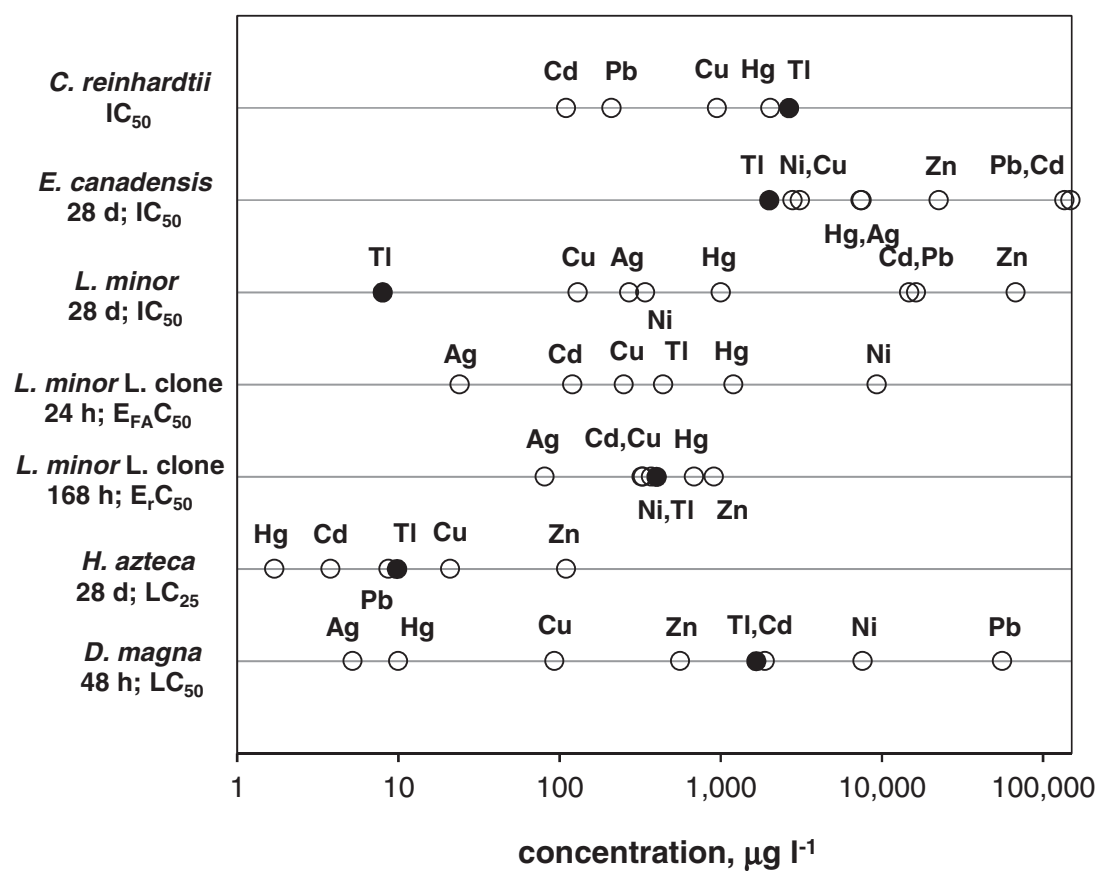

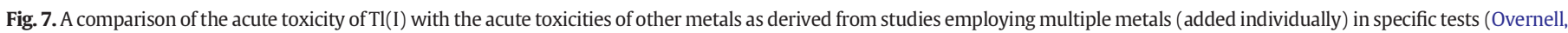
1975; Brown and Rattigan, 1979; Naumann et al., 2007; Henke et al., 2011; Borgmann et al., 1998; Lin et al., 2005). 


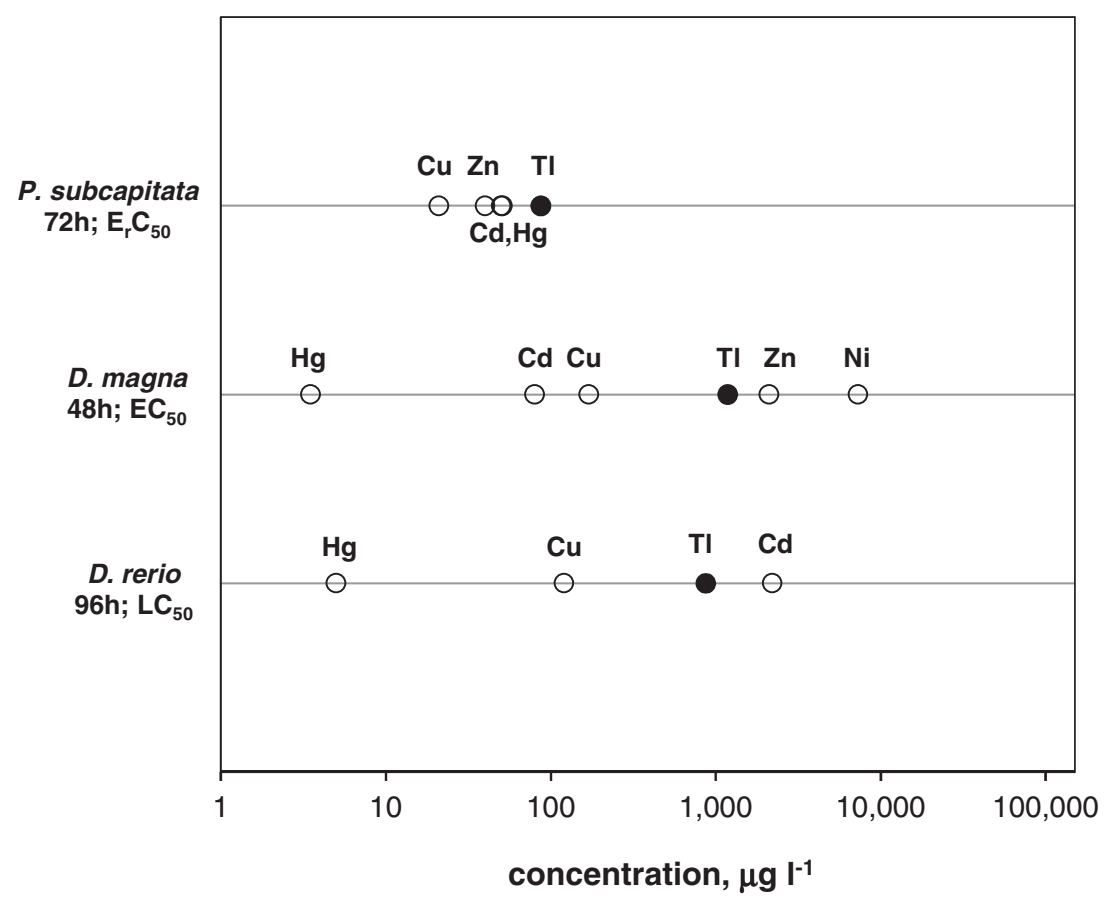

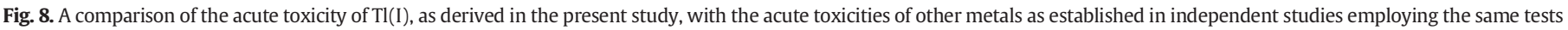
and end-points (Martins et al., 2007; Rodrigues et al., 2013; Machado and Soares, 2014).

Given the effects of $\mathrm{K}^{+}$, Tl toxicity may also be expressed in terms of its abundance relative to that of its analogue. On this basis, and using concentrations of $\mathrm{K}^{+}$in Table 1 and the data in Table 2, toxicity ranges from $\mathrm{Tl}^{+}$to $\mathrm{K}^{+}$ratios of 0.017 ( $72 \mathrm{~h} \mathrm{E}_{\mathrm{y}} \mathrm{C}_{25}$ for P. subcapitata) to about 0.5 ( $48 \mathrm{~h} \mathrm{EC}_{50}$ for $D$. pulex exposed in tap water). Regarding D. magna, when the results for tap water and OECD water in Table 2 are normalised to $\mathrm{K}^{+}$, ratios for equivalent end-points are remarkably similar $\left(\mathrm{EC}_{50} \sim 0.36, \mathrm{EC}_{25} \sim 0.26\right)$, suggesting that $\mathrm{K}^{+}$alone is responsible for differences in $\mathrm{Tl}$ toxicity between the two media. For $D$. pulex, results for the two media are closer on $\mathrm{K}^{+}$normalisation but ratios are greater (or Tl less toxic) in tap water $\left(\mathrm{EC}_{50}=0.51, \mathrm{EC}_{25}=0.40\right.$ ) than in $\mathrm{OECD}$ water $\left(\mathrm{EC}_{50}=0.33, \mathrm{EC}_{25}=0.25\right)$.

Based on toxicity and accumulation studies employing a microalga, cyanobacteria and rotifer, Hassler et al. (2007) suggest that below a threshold $\mathrm{Tl}^{+}$to $\mathrm{K}^{+}$ratio of 0.02 (or 0.004 on a molar basis), the aquatic toxicity of $\mathrm{Tl}$ to microorganisms will be suppressed. Our results are quantitatively consistent with this assertion for both invertebrates and early-life fish in that, in all cases, ratios eliciting a toxic response exceed 0.02 . However, we note $\mathrm{Tl}^{+}$to $\mathrm{K}^{+}$ratio for the NOEC to $P$. subcapitata of less than 0.01, and ratios derived from Borgmann et al. (1998) for the amphipod H. azteca and Brown and Rattigan (1979) for the macrophyte L. minor as low as 0.0036 and 0.002 , respectively. Clearly, therefore, the threshold suggested by Hassler et al. (2007) does not apply to a wider range of aquatic organisms.

\subsection{Regulatory context}

The only environmental fresh water quality guideline for $\mathrm{Tl}$ that appears to have been developed with a clear rationale is that described by the Canadian Council of Ministers of the Environment (CCME, 1999). Here, a guideline of $0.8 \mu \mathrm{g} \mathrm{l} \mathrm{l}^{-1}$ was derived from the chronic ( $28 \mathrm{~d}, 50 \%$ whole plant damage) toxicity of $\mathrm{Tl}(\mathrm{I})$ to the macrophyte, $L$. minor (Brown and Rattigan, 1979), the most sensitive aquatic organism/ end-point reported at the time, multiplied by a safety factor of 0.1 . Since the publication of the guideline, more data have emerged on a wider variety of aquatic organisms, including toxicities lower than the concentration on which the guideline was based. Significantly, many subsequent studies have shown a clear dependence of Tl toxicity on the relative abundance of $\mathrm{K}^{+}$, and toxic effects at concentrations of less than $2 \mu \mathrm{g} \mathrm{l}{ }^{-1}$ in the absence of this cation in some cases. Thus, it would appear that the water quality guideline for $\mathrm{Tl}$ should be revised downward, and should factor in some dependence on $\mathrm{K}^{+}$concentration (or employ a $\mathrm{Tl}^{+}$to $\mathrm{K}^{+}$ratio; see Section 4.3).

Because we used three trophic levels with suitable end-points and timescales and undertook the assays according to established guidelines, the acute toxicity data generated in the present study satisfy accepted criteria for deriving a predicted no effect concentration (PNEC), or an environmental concentration at and below which adverse effects in exposed organisms are unlikely (Hahn et al., 2013). According to the European Union Water Framework Directive (European Communities, 2011), when only acute toxicity data are available for three trophic levels, a protective factor of 1000 should be applied to the lowest end-point concentration ( $a \mathrm{EC}_{50}$ or $\mathrm{LC}_{50}$ ) determined. Specifically, our $72 \mathrm{~h} \mathrm{E}_{\mathrm{r}} \mathrm{C}_{50}$ for P. subcapitata yields a PNEC of $0.087 \mu \mathrm{g} \mathrm{l^{-1 }}$, or an order of magnitude lower than the CCME water quality guideline. Risk may then be evaluated by dividing a predicted (environmental) exposure concentration, PEC, by the PNEC, where a hazard quotient exceeding 1 indicates potential toxicity and it is advised that the chemical is further investigated on a site-specific basis (Hahn et al., 2013). Regarding rivers, a global average (background) aqueous concentration of $\mathrm{Tl}$ of about $0.007 \mu \mathrm{g}^{-1}$ has been estimated (Nielsen et al., 2005), resulting in a "global" hazard ratio of about 0.08 . However, in areas impacted by historical or contemporary metal or coal mining, $\mathrm{Tl}$ concentrations in excess of $5 \mu \mathrm{g} \mathrm{l}^{-1}$ have been reported (Cheam, 2001; Casiot et al., 2011), resulting in a hazard ratio in excess of 50. On this basis, such regions would clearly be of concern regarding $\mathrm{Tl}$ contamination. However, as with the water quality guideline approach outlined above (CCME, 1999), this means of risk assessment does not account for water characteristics, and in particular the competitive effects of $\mathrm{K}^{+}$.

\section{Conclusions}

This is the first study to determine the acute toxicity of $\mathrm{Tl}(\mathrm{I})$ to three trophic levels according to well-established OECD guidelines. The results reveal that the microalga, $P$. subcapitata, is more sensitive to $\mathrm{Tl}$ than either species of Daphnia tested or to the early life stages of 
D. rerio. Our results suggest that a PNEC for Tl of about $0.09 \mu \mathrm{g} \mathrm{l}^{-1}$ is appropriate for freshwaters; this is an order of magnitude lower than the only available (Canadian) water quality guideline. However, given the ameliorating effects of $\mathrm{K}^{+}$on $\mathrm{Tl}^{+}$toxicity, it is recommended that further studies target the relationship between the two ions in this respect. Given the lack of measurements of $\mathrm{Tl}$ in the environment, but that concentrations are known to approach or exceed the PNEC in many regions affected by metal or coal mining, it is also recommended that $\mathrm{Tl}$ be included more widely in routine monitoring of water quality and that the metal be considered for inclusion into the European Union Water Framework Directive.

\section{Conflict of interest}

The authors declare that they have no conflicts of interest.

\section{Acknowledgements}

We thank Mr. Andy Atfield and Mr. Stanley McMahon for technical support throughout this study. Dr. Andrew Fisher is acknowledged for assistance with the ICP analyses.

\section{References}

Borgmann, U., Cheam, V., Norwood, W.P., Lechner, J., 1998. Toxicity and bioaccumulation of thallium in Hyalella azteca, with comparison to other metals and prediction of environmental impact. Environ. Pollut. 99, 105-114.

Brismar, T., 1998. Thallium transport in cellular membranes. In: Nriagu, J.O. (Ed.), Thallium in the Environment. Wiley-Interscience, London, pp. 241-261.

Brown, B.T., Rattigan, B.M., 1979. Toxicity of soluble copper and other metal ions to Elodea canadensis. Environ. Pollut. 20, 303-314.

Casiot, C., Egal, M., Bruneel, O., Verma, N., Parmentier, M., Elbaz-Poulichet, F., 2011. Predominance of aqueous $\mathrm{Tl}(\mathrm{I})$ species in the river system downstream from the abandoned Carnoulés mine (southern France). Environ. Sci. Technol. 45, 2056-2064.

CCME, 1999. Canadian water quality guidelines for the protection of aquatic life: thallium. Canadian Environmental Quality Guidelines. Canadian Council of Ministers of the Environment, Winnipeg.

Cheam, V., 2001. Thallium contamination of water in Canada. Water Qual. Res. J. Can. 36, 851-877.

Commission of the European Communities, 2006. Proposal for a Directive of the European Parliament and of the Council on Environmental Quality Standards in the Field of Water Policy and Amending Directive 2000/60/EC. COD, Brussels (2006/0129).

Couture, P., Fortin, C., Hare, L., Lapointe, D., Pitre, D., 2011. Critical review of thallium in aquatic ecosystems. Research Report No. R-1272. Environment Canada, Gatineau, QC.

EPA, 1980. Ambient Water Quality Criteria for Thallium. United States Environmental Protection Agency, Office of Water Regulations and Standards Criteria and Standards Division, Washington.

European Communities, 2011. Common Implementation Strategy for the Water Framework Directive (2000/60/EC). Guidance Document No. 27, Technical Guidance for Deriving Environmental Quality Standards (Brussels).

Galvan-Arzate, S., Santamaria, A., 1998. Thallium toxicity. Toxicol. Lett. 99, 1-13.

Hahn, T., Diamond, J., Dobson, S., Howe, P., Kielhorn, J., Koennecker, G., Lee-Sterne, C., Mangelsdorf, I., Schneider, U., Sugaya, Y., Taylor, K., van Dam, R., Stauber, J.L., 2013. Predicted no effect concentration derivation as a significant source of variability in environmental hazard assessments of chemicals in aquatic systems: an international analysis. Integr. Environ. Assess. Manag. 10, 30-36.

Hassler, C.S., Chafin, R.D., Klinger, M.B., Twiss, M.R., 2007. Application of the biotic ligand model to explain potassium interaction with thallium uptake and toxicity to plankton. Environ. Toxicol. Chem. 26, 1139-1145.
Henke, R., Eberius, M., Appenroth, K.J., 2011. Induction of frond abscission by metals and other toxic compounds in Lemna minor. Aquat. Toxicol. 101, 261-265.

Jessop, A., Turner, A., 2011. Leaching of $\mathrm{Cu}$ and $\mathrm{Zn}$ from discarded boat paint particles into tap water and rain water. Chemosphere 83, 1575-1580.

Kaplan, D.I., Mattigod, S.V., 1998. Aqueous geochemistry of thallium. In: Nriagu, J.O. (Ed.), Thallium in the Environment. Wiley-Interscience, London, pp. 15-29.

Kwan, K.H.M., Smith, S., 1988. The effect of thallium on the growth of Lemna minor and plant tissue concentrations in relation to both exposure and toxicity. Environ. Pollut. 52, 2013-2219.

LeBlanc, G.A., Dean, J.W., 1984. Antimony and thallium toxicity to embryos and larvae of fathead minnows (Pimephales promelas). Bull. Environ. Contam. Toxicol. 32, 565-569.

Lin, T.S., Meier, P., Nriagu, J., 2005. Acute toxicity of thallium to Daphnia magna and Ceriodaphnia dubia. Bull. Environ. Contam. Toxicol. 75, 350-355.

Lustigman, B., Lee, L.H., Morata, J., Khan, F., 2000. Effect of thallium on the growth of Anacystis nidulans and Chlamydomonas reinhardtii. Bull. Environ. Contam. Toxicol. 64, 565-573.

Machado, M.D., Soares, E.V., 2014. Modification of cell volume and proliferative capacity of Pseudokirchneriella subcapitata cells exposed to metal stress. Aquat. Toxicol. 147, 1-6.

Martins, J., Teles, L.O., Vasconcelos, V., 2007. Assays with Daphnia magna and Danio rerio as alert systems in aquatic toxicology. Environ. Int. 33, 414-425.

Naumann, B., Eberius, M., Appenroth, K.J., 2007. Growth rate based dose-response relationships and EC-values of ten heavy metals using the duckweed growth inhibition test (ISO 20079) with Lemna minor L. clone St. J. Plant Physiol. 164, 1656-1664.

Nielsen, S.G., Rehkämper, M., Porcelli, D., Andresson, P., Halliday, A.N., Swarzenski, P.W. Latkoczy, C., Günther, G., 2005. Thallium isotope composition of the upper continental crust and rivers - an investigation of the continental sources of dissolved marine thallium. Geochim. Cosmochim. Acta 69, 2007-2019.

OECD, 1992. Fish, Early-life Stage Toxicity Test. Organisation for Economic Cooperation and Development Guideline for Testing of Chemicals, p. 210.

OECD, 2004. Daphnia sp. Acute Immobilisation Test. Organisation for Economic Cooperation and Development Guideline for Testing of Chemicals, p. 202.

OECD, 2006. Freshwater Alga and Cyanobacteria, Growth Inhibition Test. Organisation for Economic Cooperation and Development Guideline for Testing of Chemicals, p. 201

Overnell, J., 1975. The effect of some heavy metal ions on photosynthesis in a freshwater alga. Pest Biochem. Physiol. 5, 19-26.

Peter, A.L.J., Viraraghavan, T., 2005. Thallium: a review of public health and environmental concerns. Environ. Int. 31, 493-501.

Pickard, J., Yang, R., Duncan, B., McDevitt, C.A., Eickhoff, C., 2001. Acute and sublethal toxicity of thallium to aquatic organisms. Bull. Environ. Contam. Toxicol. 66, 94-101.

Ralph, L., Twiss, M.R., 2002. Comparative toxicity of thallium(I), thallium(III), and cadmium(II) to the unicellular alga Chlorella isolated from Lake Erie. Bull. Environ. Contam. Toxicol. 68, 261-268.

Rickwood, C.J., King, M., Huntsman-Mapila, S., 2015. Assessing the fate and toxicity of thallium I and thallium III to three aquatic organisms. Ecotoxicol. Environ. Saf. 115, 300-308.

Rodrigues, A.C.M., Jesus, F.T., Fernandes, M.A.F., Morgado, F., Soares, A.M.V.M., Abreu, S.N. 2013. Mercury toxicity to freshwater organisms: extrapolation using species sensitivity distributions. Bull. Environ. Contam. Toxicol. 91, 191-196.

Smith, I.C., Carson, B.L., 1977. Trace Metals in the Environment, Volume 1 - Thallium. Ann Arbor Science, Ann Arbor, Michigan.

Tatsi, K., Turner, A., 2014. Distributions and concentrations of thallium in surface waters of a region impacted by historical metal mining (Cornwall, UK). Sci. Total Environ. 473-474, 139-146.

Turner, A., Cabon, A., Glegg, G.A., Fisher, A.S., 2010. Sediment-water interactions of thallium under simulated estuarine conditions. Geochim. Cosmochim. Acta 74, 6779-6787.

Twiss, M.R., Twining, B.S., Fisher, N.S., 2004. Bioconcentration of inorganic and organic thallium by freshwater phytoplankton. Environ. Toxicol. Chem. 23, 968-973.

Velasco-Santamaría, Y.M., Handy, R.D., Sloman, K.A., 2011. Endosulfan affects health variables in adult zebrafish (Danio rerio) and induces alterations in larvae development. Comp. Biochem. Physiol. C Toxicol. Pharmacol. 153, 372-380.

Zitko, V., Carson, W.V., Carson, W.G., 1975. Thallium: occurrence in the environment and toxicity to fish. Bull. Environ. Contam. Toxicol. 13, 23-27. 